\title{
Potential of Rice Culture Starter (RCS) for Pre- fermenting Parboiled Rice Bran (PRB) Through Solid-state Fermentation (SSF)
}

\author{
Tules P. Banwa*, Maria Cyrila Bawer and Joy Grace P. Doctor \\ Kalinga State University (KSU), Tabuk City, Kalinga, Philippines
}

\section{Article Type: Article}

Article Citation: Tules P. Banwa, Maria Cyrila Bawer, Joy Grace P. Potential of rice culture starter (RCS) for pre-fermenting parboiled rice bran (PRB) through solid-state fermentation (SSF). Indian Journal of Science and Technology.2020;13(09), 1035-1045.D0l: 10.17485/ijst/2020/v013i09/148117

Received date: 0 ctober 13, 2019

Accepted date: November 20, 2019

*Author for correspondence:

Tules P. Banwa banwatules@gmail. com 9 Kalinga State University (KSU), Tabuk City, Kalinga, Philippines

\begin{abstract}
Objectives: Traditional fermentation uses culture starters to convert farm by-products into nutritive substances. This study investigated the potential of rice culture starter (RCS) in pre-fermenting parboiled rice bran (PRB) into a nutritive mash. Methods/statistical analysis: This study used the completely randomized design in triplicate. Three mixtures ratio of RCS and PRB served as experimental treatments, while PRB without RCS was used as the control treatment. The treatments have undergone the traditional solid-state fermentation at $72 \mathrm{~h}, 120 \mathrm{~h}$, and $192 \mathrm{~h}$. The treatment means were compared using the $f$-test, and significant means were compared to the least significant difference (LSD) using the SPSS version 16. Findings: The experimental treatments show a significantly higher fermented PRB mash volume and lower $\mathrm{pH}$ compared to the control treatment, indicating significant fermentation of PRB substrates by RCS. The mixture ratio of 12:100 parts of RCS and PRB respectively shows a significantly higher PRB mash volume after 72 hours compared to the other mixture ratios. Chemical analysis of fermented PRB shows $4.90 \%$ ash content similar to the contents of stabilized and probiotic rice bran, and other nutritive substances. This study shows the potential of pre-fermenting agricultural biomass substrates through traditional solid-state fermentation into nutritive elements. Furthermore, this study demonstrates the practical use of traditional starter cultures, including RCS that can benefit farmers directly. Application: This study showed that the rice culture starter could be used in biomass conversions, which can be adopted by ordinary people using traditional fermentation technology.
\end{abstract}

Keywords: Rice Culture Starter, Parboiled Rice Bran, SolidFermentation, Pre-Fermentation. 


\section{Introduction}

Traditional fermentation technology using starter cultures [1] in fermenting foods for consumption started since the start of human civilization [2]. Practical solid-state fermentation technology uses readily made traditional starter cultures.

In rice-producing countries, the traditional rice starter culture is known in different names; xaj-pitha in Assam, India, chu in China, koji in Japan, banh men in Vietnam, murcha in India, ragi in Indonesia, ragitapai in Malaysia [3], nuruk in Korea [4], medomdaeor mesra in Cambodia [5], and bubod in the Philippines [6-9].

Rice starter cultures are a mixture of molds, yeasts, and bacteria maintained on solid substrate likes rice powder with different herbs supplements. Metagenomics analysis of Indian xaj-pitha showed the presence of amylase producers, ethanol producers, dominant communities of lactic acid bacteria, and a diverse range of opportunistic contaminants [3]. The South Korean rice wine starter nuruk contain fungi and bacteria since it is prepared from unsterilized grains [4]. Microbial analysis of different Chinese rice starter materials revealed the coexistence of bacteria, three mold species (Mucor cirnelloides, Mucor grisecyanus, and Rhizopis cohnii) and two yeast species (Saccharomyces cerevisiae and Sacchromycopsis fibuligera). Likewise, the microbial analysis Philippines rice starter culture (bubod) and rice wine (tapuy) showed 36 mold species, 62 acid-producing bacteria, and 100 yeast strains. Besides, Genus Saccharomycopsis and Saccharomyces were presumed to play significant roles in saccharification and alcohol fermentation, respectively, of rice wine in the mountainous Cordillera Region of Northern Philippines during parallel fermentation [10].

The Philippines ' traditional rice starter cultures are mixed directly with steamed rice and allowed to undergo solid-state fermentation (SSF) as the initial stage of rice wine production [6-9]. SSF is ideal for fungi and microorganisms that require less moisture content with solid substrates. The low moisture content in the SSF media favors the use of fungi because of their ability to grow in these environments [11]. However, SSF cannot be used for organisms that require high water activity, such as bacteria [12].

Aside from producing traditional wines, the improvement of solid-state fermentation (SSF) using different substrates led to the production of compounds with economic, industrial, and medical importance. These compounds include probiotics and prebiotics, pharmaceuticals [12], antibiotics, peptides, enzymes and growth factors, mycotoxins, bacterial endotoxins, alkaloids, plant growth factors, antibiotics, immune-suppressive drugs, food-grade pigments, phenolic compounds [11] biofuels, food flavors, enzymes, bioactive compounds, and antibiotics [13].

The unexploited biomass [13] and agro-industrial wastes [11] can be used as solid substrates for SSF. These agricultural by-products include wheat bran, rice bran and rice straw, hay, fruit and vegetable waste, paper pulp, bagasse, coconut coir, and even synthetic media [12, 14-15], forest residues that are abundant and underutilized [16]. Rice bran is one of the underutilized agricultural by-products of Kalinga province, the rice granary of the Cordillera Region, Philippines [17]. Modern rice mills produce 70 percent rice endosperm, 20 percent husk, 8 percent rice bran, and 2 percent rice germ [18]. Annually, 63-76 million tons of rice bran are produced worldwide, and about 90 percent of this is 
used as animal feed [19]. The use of these readily cheap available agro-industrial wastes is economical, environment-friendly, and alternative disposal [11].

Agricultural residues, including rice bran, have potential uses as feedstuffs and chemical feedstock [20]. Of the agricultural by-products, rice bran is considered the cheapest residue and supportive substrate for enzyme (lipase) production compared to other agricultural residues [21]. Rice bran was used as substrates in screening nine strains of Rhizopus species for neutral protease production through SSF [22].

While rice bran is used as a substrate for specific microbes to produce enzymes, little is known about using it as substrates for traditional rice starter culture to produce nutritive substances of economic importance. This preliminary study explored the potential of using the Kalinga bubod to ferment parboiled rice bran; determine the liquid product volume and $\mathrm{pH}$ of the different mixtures of rice starter culture and parboiled rice bran at different fermentation periods and determine nutritional contents of the fermented parboiled rice bran.

This study presents the possibility of using a rice culture starter (RCS) as a possible inoculant of converting agricultural wastes through SSF into products for possible humans and livestock consumption.

\section{Materials and Methods}

The general flowchart of the methodology of the study is presented in Figure 1.

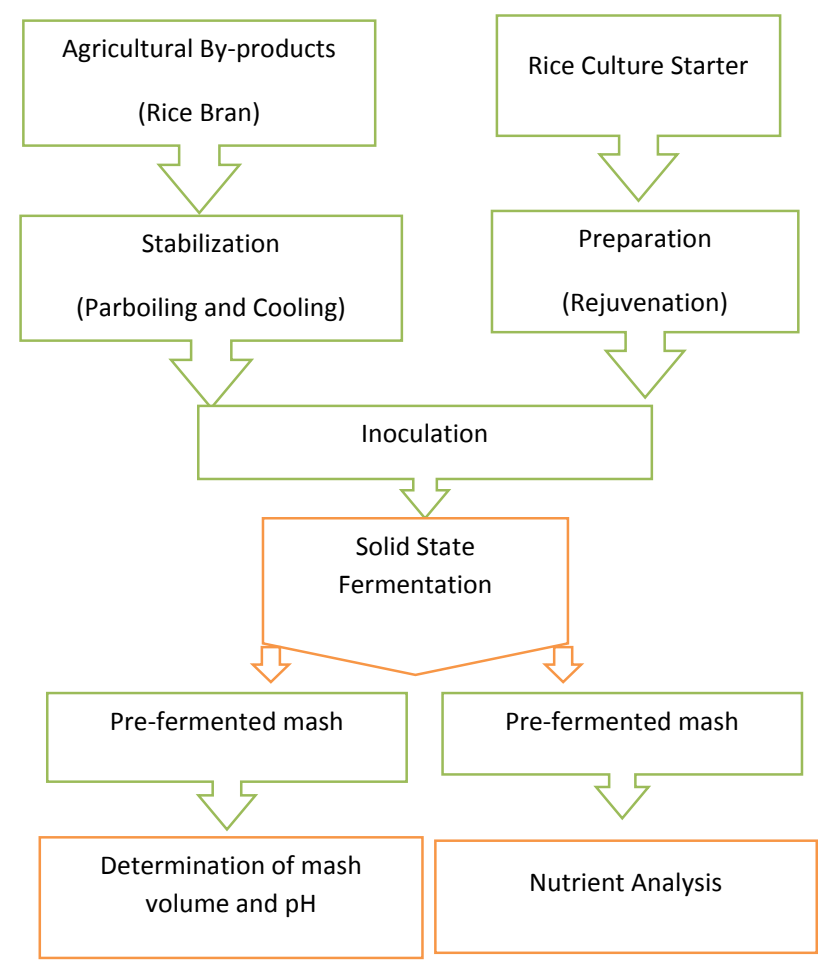

FIGURE 1. Flowchart of the methodology of the study. 


\subsection{Experimental Design}

A complete randomized design (CRD) was adopted in this study. A total of 36 treatments were generated from four treatments, three replications, and three fermentation durations. The following mixture ratios were used as treatments; $\mathrm{T}_{1^{-}} 9 \mathrm{~g}$ rice culture starter $(\mathrm{RCS})+$ 1000 g parboiled rice bran (PRB), $\mathrm{T}_{2}-12 \mathrm{~g}$ RCS $+1000 \mathrm{~g}$ PRB, $\mathrm{T}_{3^{-}} 15 \mathrm{~g}$ RCS $+1000 \mathrm{~g}$ PRB, $\mathrm{T}_{4^{-}}$(control) $1000 \mathrm{~g}$ PRB without RCS. The different treatments were subjected to $72 \mathrm{~h}$, $120 \mathrm{~h}$, and $192 \mathrm{~h} \mathrm{SSF}$, respectively. The mixture ratio of $12 \mathrm{~g} \mathrm{RCS}: 1000 \mathrm{~g}$ PRB was adopted from the traditional rice wine preparation. The other mixture ratios were adjusted for comparisons.

\subsection{Preparation of Rice Bran}

A sample of raw rice was purchased from the local market. The samples were screened using a fine mesh strainer to remove remaining husks and solid particles. A standard weighing scale was used to weigh $1000 \mathrm{~g}$ screened rice bran.

\subsection{Stabilization of Rice Bran}

The traditional mixture ratio of rice and water [6] in rice wine preparation was adopted in this study with modification. A $1250 \mathrm{~mL}$ tap water was measured using a graduated cylinder, poured into a stainless pot, heated using a liquefied petroleum gas (LPG) gas stove until it boiled, and then $1000 \mathrm{~g}$ rice bran was gradually mixed by continuously stirring using a wooden spoon for 10 min under slow fire. Parboiling can deactivate lipase [19]. Besides, heating is the most practical and inexpensive method to deactivate lipase in rice bran [23-24]. Rice bran has a natural tendency to turn rancid due to its lipase activity [18-23].

\subsection{Starter Culture Preparation and Rejuvenation}

The preparation of the Philippine bubod was described as follows [6]; washing and soaking of glutinous rice overnight, drained, powdered, mixed with wild herb (onwad) roots, ginger and sufficient water, rolling the mixture into a ball then flattened, sprinkling the surface with old starter culture in layers using dried rice straw as separators, incubating for $24 \mathrm{~h}$ at about $30^{\circ} \mathrm{C}$ to $35^{\circ} \mathrm{C}$ then sun-dried for 3-5 days and rejuvenating starter culture after 3 months to maintain the viability of the microorganisms. A cake of Kalinga bubod weighed about $50 \mathrm{~g}$.

\subsection{Inoculation}

The PRB was placed in a stainless metal tray and allowed to cool at room temperature [25-26] for at least an hour. Upon cooling, the treatments were prepared in triplicates. The experimental treatments were inoculated by mixing powdered rice starter culture [6] with the PRB. 


\subsection{Traditional Solid-State Fermentation}

The advantage of traditional SSF is the use of cheaper substrates, including agricultural byproducts [27]. The traditional SSF of preparing rice wine [6] was adopted in this study using the simplest bag system type of bioreactor [15]. The different treatments with varying fermentation durations of $72 \mathrm{~h}, 120 \mathrm{~h}$, and $192 \mathrm{~h}$ were prepared simultaneously in triplicates, placed separately inside a transparent roll-up plastic (Pagoda), sealed, stored in plastic trays, and arranged following the complete randomized design (CRD). The treatments were allowed to ferment at an ambient temperature of $24^{\circ} \mathrm{C}$ to $3{ }^{\circ} \mathrm{C}$. The ambient temperature for rice wine fermentation with RSC ranges from $28^{\circ} \mathrm{C}$ to $30^{\circ} \mathrm{C}$ [6] and $30^{\circ} \mathrm{C}$ to $38^{\circ} \mathrm{C}$ [5]. Closed plastic provided a good fermentation system in producing rice wine during solid-state fermentation [28].

\subsection{Mash Extraction and Determination of Volume}

At the fermentation duration of $72 \mathrm{~h}, 120 \mathrm{~h}$, and $192 \mathrm{~h}$, triplicates of the different treatments were withdrawn. The mash from fermented PRB was extracted manually using a sterilized cotton cloth. The volume of the mash was measured using a standard laboratory graduated cylinder (100 mL, with $1 \mathrm{~mL}$ graduation)

\section{8. pH Determination}

About $100 \mathrm{~mL}$ of PRB mash was poured into a beaker $(250 \mathrm{~mL})$ for $\mathrm{pH}$ measurement. After calibrating the digital $\mathrm{pH}$ meter with a buffer solution at $7 \mathrm{pH}$, the $\mathrm{pH}$ of the different treatments was determined.

\subsection{Estimation of the Chemical Contents of the Fermented PRB}

The ash, crude fat, crude protein, and moisture contents of the fermented PRB were estimated and expressed in percentage (\%) based on AOAC Official Methods, 20th Edition 2016. The sodium content $(\mathrm{Na})$ of the fermented rice bran was estimated through dry ashing, acid digestion, and quantitation by inductively coupled plasma-optical emission spectrometry (ICP-OCES) and expressed in $\mathrm{mg} / 100 \mathrm{~g}$. The calories from carbohydrates, fats, and protein were estimated through computation and expressed in percentage (\%). The total calories and carbohydrates were determined by calculation and showed in percent (\%).

\subsection{Statistical Treatments}

The mash volume and $\mathrm{pH}$ of the different treatments were expressed as the mean values. The experimental and control treatment means were compared using the analysis of variance. Significantly different means were further examined using the multiple comparisons of the means (LSD). The 0.05 level of significance was used in this study. SPSS v 16 was used to analyze the data. 


\section{Results and Discussions}

\subsection{The Volume of Mash at Various Fermentation Durations}

The volume of the mash extracted from the different treatments at the varying duration of SSF is shown in Figure 2. Generally, it shows an increase in the mean volume of the mash produced of all the treatments as fermentation durations increase. This result indicates that fermentation product is directly related to time [29], wherein incubation time directly affects the production of cordycepin from various substrates, including rice during SSF. Likewise, the time has a linear effect on the production of protein from rice bran fermented with baker's yeast [30].

It is interesting to note that the treatment without RCS $\left(\mathrm{T}_{4}\right)$ consistently has the lowest mean volume of mash produced throughout the fermentation durations compared to the experimental treatments. This result indicates that the mash volume of PRB can be increased using RSC through traditional SSF technology.

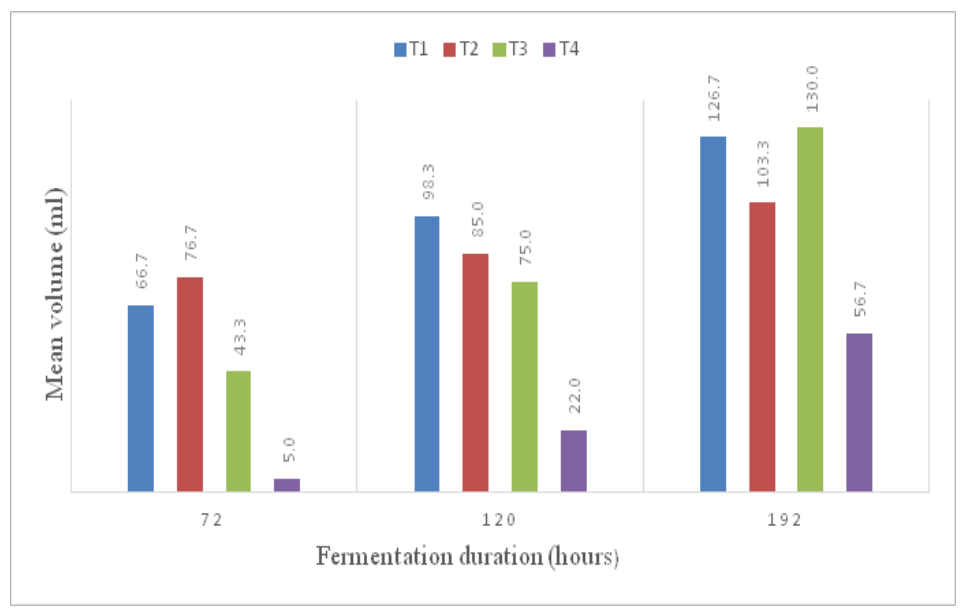

FIGURE 2. Mass volume of different treatments at various fermentation durations.

\subsection{The $\mathrm{pH}$ of Mash at Various Fermentation Durations}

The different $\mathrm{pH}$ of the treatments is shown to fluctuate during the fermentation duration (Figure 3 ). The $\mathrm{pH}$ range of $4.48-4.78$ of the various treatments at $72 \mathrm{~h}$ fermentation duration increases to a $\mathrm{pH}$ range of 5.22-5.55 after $120 \mathrm{~h}$. However, there is a gradual decrease in the $\mathrm{pH}$ range of 4.01-5.04 as the fermentation reached $192 \mathrm{~h}$.

A similar higher $\mathrm{pH}$ range of 5.82-5.88 was reported on rice bran sourdough fermented with a mixed culture of yeast and lactic acid bacteria for 16 hours [31], while those fermented with lactic producing bacterial having a significantly lower $\mathrm{pH}$ range of 4.094.11. A pH 5.5 of fermented substrates was observed after 21 days of producing cordycepin from Cordyceps militaris [29].

This decrease in the $\mathrm{pH}$ range of 3.3-5.0 was reported earlier [6] after 3-4 weeks of fermenting rice with RCS. A similar reduction of $\mathrm{pH}$ from 3.3 to 4.0 was noted after $72 \mathrm{~h}$ of fermenting rice wine with a starter culture [5]. 


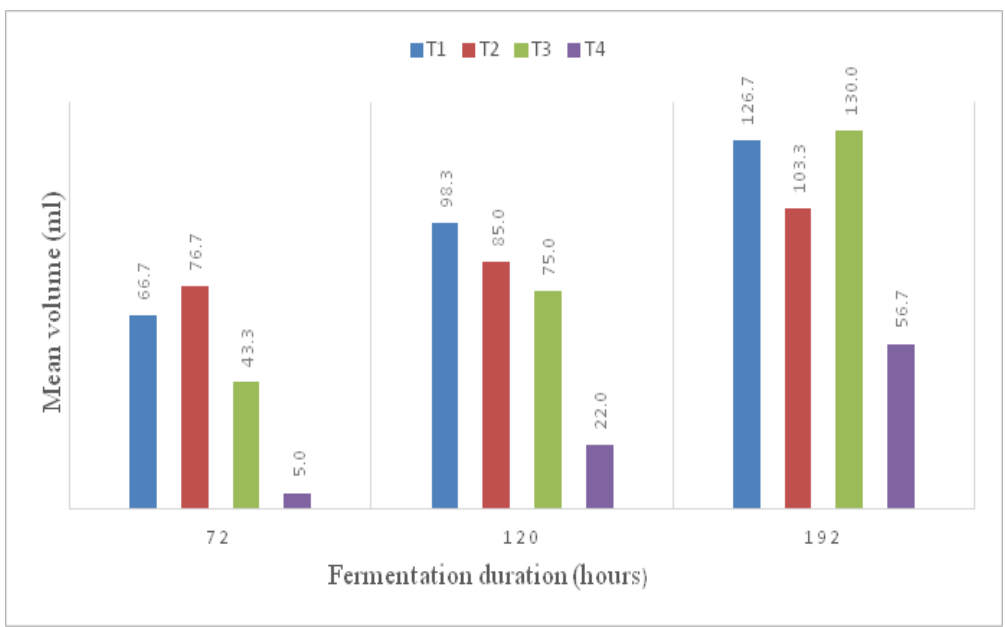

FIGURE 3. Mash pH of different treatments at various fermentation durations.

This $\mathrm{pH}$ variation indicates the presence of various microbes in the RCS that fermented the substrates into a mash. Some of the yeast strains identified are Aspergillus oryzae [9]. Saccharomycopsis fibuligera, Rhodotorula glutinis, Debaryomyces hansenii, Candida parapsilosis, Trichosporon fennicum1, and acid-producing bacteria. These could initially ferment the PRB at the early stage of solid-state fermentation. However, the acid-producing bacteria dominated [10] in the later stage of fermentation.

\subsection{Mean Differences in the Mash Volume Among Treatments}

The parboiled rice bran without rice culture starter $\left(\mathrm{T}_{4}\right)$ has a significantly lower mean mash volume of $5.00 \mathrm{~mL}, 22.00 \mathrm{~mL}$, and $56.66 \mathrm{~mL}$ at $72 \mathrm{~h}$ (Table 1a), $120 \mathrm{~h}$ (Table $1 \mathrm{~b}$ ), and $192 \mathrm{~h}$ (Table 1c) respectively compared to the experimental treatments. This finding

TABLE 1. Mean differences in mash volume and $\mathrm{pH}$ among treatments at different fermentation periods

\begin{tabular}{lcc}
\hline Treatments and fermentation periods & Mean volume $(\mathbf{m L})$ & Mean pH \\
\hline a. 72 hours: & & \\
Treatment $1\left(\mathrm{~T}_{1}\right)$ & $66.6667 \mathrm{ab}$ & $4.6600 \mathrm{~b}$ \\
Treatment $2\left(\mathrm{~T}_{2}\right)$ & $76.6667 \mathrm{a}$ & $4.7800 \mathrm{c}$ \\
Treatment $3\left(\mathrm{~T}_{3}\right)$ & $43.3333 \mathrm{~b}$ & $4.4800 \mathrm{a}$ \\
Treatment $4\left(\mathrm{~T}_{4}\right.$-control) & $5.0000 \mathrm{c}$ & $4.5500 \mathrm{a}$ \\
b. 120 hours: & & \\
Treatment $1\left(\mathrm{~T}_{1}\right)$ & $98.33 \mathrm{a}$ & $5.2800 \mathrm{~b}$ \\
Treatment $2\left(\mathrm{~T}_{2}\right)$ & $85.00 \mathrm{a}$ & $5.2233 \mathrm{a}$ \\
Treatment $3\left(\mathrm{~T}_{3}\right)$ & $75.00 \mathrm{a}$ & $5.4700 \mathrm{c}$ \\
Treatment $4\left(\mathrm{~T}_{4}\right.$-control) & $22.00 \mathrm{~b}$ & $5.5533 \mathrm{~d}$ \\
c. 192 hours: & & \\
Treatment $1\left(\mathrm{~T}_{1}\right)$ & $126.67 \mathrm{a}$ & $4.0867 \mathrm{a}$ \\
Treatment $2\left(\mathrm{~T}_{2}\right)$ & $103.33 \mathrm{a}$ & $4.0067 \mathrm{a}$ \\
Treatment $3\left(\mathrm{~T}_{3}\right)$ & $130.00 \mathrm{a}$ & $4.1433 \mathrm{a}$ \\
Treatment $4\left(\mathrm{~T}_{4}\right.$-control) & $56.6667 \mathrm{~b}$ & $5.0433 \mathrm{~b}$ \\
\hline
\end{tabular}


shows that mixing rice starter culture to the parboiled rice bran significantly increases the fermentation process during SSF.

Among the experimental mixtures, $\mathrm{T}_{2}$ shows a significantly higher mash mean volume of $76.66 \mathrm{~mL}$ at a $72 \mathrm{~h}$ fermentation (Table 1a) than the $66.66 \mathrm{ml}$ and $43.33 \mathrm{~mL}$ mean volumes of $T_{1}$ and $T_{3}$, respectively. However, there is no significant difference after $72 \mathrm{~h}$. The reported best time for enzyme production through solid fermentation ranges from 72 $\mathrm{h}$ [22] to $96 \mathrm{~h}$ [21]. However, the production of bioactive compounds gradually decreases with increasing fermentation duration [22].

\subsection{Mean Differences in Mash pH Among Treatments}

At the initial stage of $72 \mathrm{~h}$ fermentation, $\mathrm{T}_{2}$ shows a significantly higher mash $\mathrm{pH}$ mean of 4.7800 compared to the experimental and control treatments (Table 1a). However, as fermentation continues, the control treatment $\left(\mathrm{T}_{4}\right)$ shows a significantly higher mean $\mathrm{pH}$ of 5.5533 (Table 1b) and 5.0433 (Table 1c) after $120 \mathrm{~h}$ and $192 \mathrm{~h}$, respectively, when compared to the experimental treatments.

The significantly higher mean $\mathrm{pH}$ of $\mathrm{T}_{2}$ could be due to the presence of yeasts in RCS [6] that initially fermented the PRB. However, the $\mathrm{pH}$ significantly decreases among the experimental treatments as fermentation reached 120 hours period. This finding could be due to the complexity of the bacterial community [31] and the dominance of acidproducing bacteria present rice culture starter [10]. These acids producing bacteria include Lactobacillus plantarum [6-34] and L. cremoris [6].

\subsection{Content Analysis of Fermented Parboiled Rice Bran}

The chemical analysis of the fermented parboiled rice bran after $192 \mathrm{~h}$ is shown in Table 2. It reveals the remaining major nutrients for microbial growth after $192 \mathrm{~h}$ of fermentation. The fermented PRB shows 14.32 percent carbohydrate and 7.44 percent crude protein. These results are almost half of the 28.71 to 33.54 percent carbohydrates and 12.37 to 13.12 percent protein contents of raw rice bran from different milling stages, as reported from previous studies [34]. The carbohydrate content of the fermented PRB decreased because it served as the principal source of energy for fermenting microbes [35]. Rice bran can provide the necessary carbon, proteins, nitrogen, and sugar supply for microbial growth [21].

TABLE 2. Content analysis of fermented parboiled rice bran after 192 hours

\begin{tabular}{ll}
\hline Content & Amount \\
\hline Ash & $4.90 \%$ \\
Calories from fat & $81.63 \mathrm{kcal} / 100 \mathrm{~g}$ \\
Calories from protein & $29.76 \mathrm{kcal} / 100 \mathrm{~g}$ \\
Crude fat & $9.07 \%$ \\
Crude protein $(\mathrm{N} \times 6.25)$ & $7.44 \%$ \\
Moisture & $62.27 \%$ \\
Sodium $(\mathrm{Na})$ & $57.28 \mathrm{mgl} / 100 \mathrm{~g}$ \\
Total calories & $168.67 \mathrm{kcal} / 100 \mathrm{~g}$ \\
Total carbohydrates & $14.32 \%$ \\
\hline
\end{tabular}


Table 2 shows an ash content of 4.90 percent. This result confirms a similar ash content of stabilized and probiotic rice bran with 4.92 and 4.64 percent, respectively [35]. This result shows that fermented $\mathrm{PRB}$ contains the essential primary source of nutrients for fermenting microbes. Fermentation can improve rice bran nutrient contents for poultry feed [36].

\section{Conclusions}

This study concludes that the rice culture starter has the potential of converting agricultural by-products such as rice bran into nutritive pre-fermented mash through solid-state fermentation. Results show that the mixture ratio of 12:100 parts of rice culture starter and parboiled rice bran substrates produce the best results in terms of mash volume after $72 \mathrm{~h}$ of SSF.

\section{Acknowledgment}

The researchers acknowledge the inputs of the panel of technical evaluators from the Cagayan Valley Agriculture Resource and Development Consortium, the Testing and Standards Division of the Department of Science and Technology (DOST) Region 2, Tuguegarao City, Cagayan Province, Philippines, for the assistance in handling and processing the fermented parboiled rice bran samples for chemical analysis by SGS Philippines Incorporated.

\section{References}

1. Aidoo KE, Rob Nout MJ, Sarkar PK. Occurrence and function of yeasts in Asian indigenous fermented foods. FEMS Yeast Research. 2006, 6 (1), 30-39.

2. Admassie M. A Review on food fermentation and the biotechnology of lactic acid bacteria. World Journal of Food Science and Technology. 2018, 2(1), 19-23.

3. Bora SS, Keot J, Das S, Sarma K, Barooah M. Metagenomics analysis of microbial communities associated with a traditional rice wine starter culture (Xaj-pitha) of Assam, India. 3 Biotech. 2016, 6(2), 1-13.

4. Yang S, Lee J, Kwak J, Kim K, Seo M, Lee YW. Fungi associated with the traditional starter cultures used for rice wine in Korea. Journal of the Korean Society for Applied Biological Chemistry. 2011, 54(6), 933-943.

5. Chim C, Erlinda ID, Elegado FB, Hurtada AW, Chakrya N, Raymundo CL. Traditional dried starter culture (Medombae) for rice liquor production in Cambodia. International Food Research Journal. 2015, 22(4), 1642-1650.

6. Sanchez C. Microorganisms and technology fermented foods of the Philippine. Japanese journal of Lactic Acid Bacteria. 1999, 10(1), 19-28.

7. Bubod [starter culture] rejuvenation: a step towards maintaining rice wine quality. http://agris. fao.org/agris-search/search.do?recordID=PH2008000683. Date accessed: 01/02/2019.

8. Standardization of starter culture for rice wine (tapuy) processing. http://agris.fao.org/agrissearch/search.do?recordID=PH2010000369. Date accessed: 01/02/2019. 
9. Some factors affecting the production of rice wine using an isolate of Aspergillus oryzae [study conducted in the Philippines]. http://agris.fao.org/agris-search/search. do? recordID=XB8210707. Date accessed: 03/03/2019

10. Kozaki M, Uchimura T. Micro-organisms in Chinese starter 'bubod' and rice wine 'tapuy' in the Philippines. Journal of The Brewing Society of Japan. 1990, 85(11), 818-824.

11. Mussatto SI, Machado EM, Carneiro LM, Teixeira JA. Sugars metabolism and ethanol production by different yeast strains from the coffee industry wastes hydrolysates. Applied Energy. 2012, 92, 763-768.

12. Subramaniyam R, Vimala R. Solid-State and submerged fermentation for the production of bioactive substances : a comparative study. International Journal of Science and Nature. 2012, 3(3), 480-486.

13. Lizardi-Jiménez MA, Hernández-Martínez R. Solid-state fermentation (SSF): diversity of applications to valorize waste and biomass. 3 Biotech. 2017, 7(1), 44.

14. Pandey A, Selvakumar P, Soccol C, Nigam P. Solid-state fermentation for the production of industrial enzymes. Current Science. 1999, 149-162.

15. Introduction to solid-state fermentation bioreactors. https://link.springer.com/ chapter/10.1007/3-540-31286-2_3. Date accessed: 04/04/2019.

16. Soccol CR, Costa ESF. da, Letti LAJ, Karp SG, Woiciechowski AL, Vandenberghe LP, de S. Recent developments and innovations in solid-state fermentation. Biotechnology Research and Innovation. 2017, 1(1), 52-71.

17. Calimag JP. The migrants of Kalinga : focus on their life and experiences. International Journal of Advanced Research in Management and Social Sciences. 2016, 5(6), 937-961.

18. Esa NM, Ling TB, Peng LS. By-products of rice processing: an overview of health benefits and applications. Rice Research: Open Access. 2016, 4(1), 1-11.

19. Rice bran: production, composition, functionality and food applications, physiological benefits. https://naldc.nal.usda.gov/download/33504/PDF. Date accessed: 15/3/2019.

20. Yazid N, Barrena R, Komilis D, Sánchez A. Solid-state fermentation as a novel paradigm for organic waste valorization: a review. Sustainability (Switzerland). 2017, 9(2), 1-28.

21. Mohseni S, Najafpour GD, Vaseghi Z, Mahjoub S. Solid-state fermentation of agricultural residues for lipase production in a tray-bioreactor. World Applied Sciences Journal. 2012, 16(7), 1034-1039.

22. Sumantha A, Larroche C, Pandey A. Microbiology and industrial biotechnology of food-grade proteases : a perspective. Food Technology and Biotechnology. 2006, 44(2), 211-220.

23. Sharma R, Srivastava T, Saxena DC. Studies on rice bran and its benefits-a review 1. Journal of Engineering Research and Applications. 2015, 5(52), 107-112.

24. Akhter M, Amjad F, Muzammil HS, Haider Z, Zia S. Studies to determine the effect of storage on extrusion stabilized raw and parboiled rice bran. International Journal of Development Research. 2016, 4(9), 1966-1969.

25. Maji J, Chandra BM, Mitra S, Biswas SR. Molecular characterization of yeasts and bacteria isolated from Handia, an Indian traditional rice fermented alcoholic beverage. American Journal of Current Microbiology. 2019, 6(1), 1-5.

26. Palaniveloo K, Vairappan CS. Biochemical properties of rice wine produced from three different starter cultures. Journal of Tropical Biology and Conservation. 2013, 10(10), 31-41.

27. Microbial fermentation strategies for biomass conversion. https://www.researchgate.net/ publication/312152103_Microbial_Fermentation_Strategies_for_Biomass_Conversion. Date accessed: 12/2017.

28. Fermented rice-Tapai. https://www.pinterest.com/pin/205124958010945612/. Date accessed: February 2, 2019. 
29. Adnan M, Ashraf SA, Khan S, Alshammari E, Awadelkareem AM. Effect of pH, temperature and incubation time on cordycepin production from Cordyceps militaris using solid-state fermentation on various substrates. CYTA - Journal of Food. 2017, 15(4), 617-621.

30. Chinma CE, Ilowefah M, Muhammad K. Optimization of rice bran fermentation conditions enhanced by Baker's yeast for extraction of protein concentrate. Nigerian Food Journal. 2014, 32(1), 126-132.

31. Lactic acid bacteria in Philippine traditional fermented foods. https://www.intechopen.com/ books/lactic-acid-bacteria-r-d-for-food-health-and-livestock-purposes/lactic-acid-bacteriain-philippine-traditional-fermented-foods. Date accessed: 30/01/2013.

32. Muhammad K, Haniz-Syazwani M, Bolarinwa IF, Lasekan O. Influence of starter culture on the physicochemical properties of rice bran. Food Research. 2018, 340-349.

33. Wu H, Zhang S, Ma Y, Zhou J, Luo H, Yang J. Comparison of microbial communities in the fermentation starter used to brew Xiaoqu liquor. Journal of the Institute of Brewing. 2017, 123(1), 113-120.

34. Rosniyana A, Hashifah MA, Norin SAS. The physicochemical properties and nutritional composition of rice bran produced at different milling degrees of rice. Journal of Tropical Agriculture and Food Science. 2007, 35(1), 99-105.

35. Bhosale S, Vijayalakshmi D. Processing and nutritional composition of rice bran. Current Research in Nutrition and Food Science. 2015, 3(1), 74-80.

36. Supriyati T, Haryati T, Susanti, Susana IWR. Nutritional value of rice bran fermented by Bacillus amyloliquefaciens and humic substances and its utilization as a feed ingredient for broiler chickens. Asian-Australasian Journal of Animal Sciences. 2017, 28(2), 231-238. 